\title{
THE IMAGE OF THE WEST IN CONSPIRACY THEORIES IN SLOVAKIA AND ITS HISTORICAL CONTEXT
}

\author{
Zuzana Panczová \\ Institute of Ethnology \\ Slovak Academy of Sciences, Bratislava, Slovakia \\ e-mail: Zuzana.Panczova@savba.sk
}

\begin{abstract}
This paper presents one of the typical features of conspiracy theories the dualistic worldview, which explains important events as a consequence of hidden struggle between 'Us' and the dark forces. An example of this characteristic also presents the dichotomous terms 'West' and 'East', which have their set of geopolitical and cultural (as well as axiological) connotations. As a political and moral concept, 'West' is particularly highly utilised in the conspiratorial discourse in Slovakia. The paper attempts to discuss the functions of this concept in rumours and conspiracy theories with regard to the local historical context, and to reveal its ties to other images of the 'enemy', frequently used in rumours circulating on popular Slovak websites. Besides conspiracy theories as such, the focus of the analysis is set also on the narratives (among others also urban legends) supporting conspiratorial suspicions, as well as on various kinds of argumentation strategies leading to cooperation (or even fusion) of seemingly contradictory ideological worldviews (left- and right-wing supporters, Christians and white supremacists, etc.).
\end{abstract}

Keywords: alternative media, conspiracy theory, conspiratorial discourse, images of enemy, nationalism, rumour, Slovakia, West

\section{INTRODUCTION}

Conspiracy theories as a specific kind of rumour-based statements are interesting objects of research in social science because of their impact on group beliefs and acting. They often create specific narratives or narrative schemes with established topics and cycles, their contents spread mostly spontaneously through the 'conduits' of supporters and produce a complex system of conspiracy culture. Therefore, they are perceived as an interesting object of research also for contemporary folklore or narrative studies.

Conspiracy theories as an established type of public discourse in Slovakia are currently experiencing their peak period. In the framework of my ethnological 
and folkloristic specialisation, I have studied conspiracy theories as an ideological type of rumours based both on the current topics of social discourse and on handed-down images of the enemy.

The typical features of conspiracy theories have been summarised by many authors, among them Michael Barkun, who in his well-known work about the culture of conspiracy presents three basic characteristics:

Nothing happens by accident. Conspiracy implies a world based on intentionality, from which accident and coincidence have been removed. Anything that happens occurs because it has been willed...

Nothing is as it seems. Appearances are deceptive, because conspirators wish to deceive in order to disguise their identities or their activities. Thus the appearance of innocence is deemed to be no guarantee that an individual or group is benign.

Everything is connected. Because the conspiracists' world has no room for accident, pattern is believed to be everywhere, albeit hidden from plain view. Hence the conspiracy theorist must engage in a constant process of linkage and correlation in order to map the hidden connections. (Barkun 2013: 3-4)

Even though the beginnings of focused scientific and mass media reflections of conspiracy theories date back to the first years of the twenty-first century, it is not a completely new phenomenon. Distrust in the governing system, dissatisfaction with the current policies, changes in society, and fears from internal and external enemies (intensified mainly in the atmosphere of war conflicts) have encouraged the dissemination of (un)founded suspicions of conspiracies for centuries. ${ }^{1}$

Some experts have also observed the existence of certain contemporary trends. Véronique Campion-Vincent highlights the shift "from evil others to evil elites". According to her, "rumours accusing elites of sinister plots are not new, but they are more prominent, and especially more pervasive and complex, today" (Campion-Vincent 2005: 107). Together with Peter Knight she affirms that today's narratives "have become all-encompassing", reducing the gap between Them and Us (Campion-Vincent 2005: 109; Knight 2002: 5). In addition, Campion-Vincent highlights the changes of the impacts of these stories on society: "Extremists' views are ancient. What is new is the echo that stories of conspiracy theorists produce in the general public today" (CampionVincent 2005: 113).

Conspiratorial narratives elaborate on explanations of social phenomena as consequences of secret conspiracies, present images of enemies, traitors, and heroes. They are usually based on a bipolar perception of social processes deter- 
mined by the fight for power. This creates an ideal space for the production of ideological collages interconnecting topics from politics, religion, science or medicine.

At present, the most successful channel for the dissemination of conspiracy theories is the alternative internet media with the mainstream media as their discursive counterpart. ${ }^{2}$ Research on rumours and urban legends confirm their important role in the social organisation of trust: "In one sense, the presence of rumour reveals weakened trust in institutions" (Fine \& Ellis 2010: 111). When information from authoritative sources is considered untrustworthy and institutions are perceived as "deceptive, incompetent, and/or immoral", the facts are learned from alternate means (ibid.).

If we look at the trends in the topics of dozens of alternative conspiracysoaked media in Slovakia (with websites as the most available type of news sources), we can see that what stands out is articles that develop their theories on the basis of the division of powers into the East and the West. These terms, apart from their geographical meaning, also entail political and moral connotations. The public discourse of the last two years has been marked by the recent political events (the civil war in Ukraine, the war in Syria, the refugee crisis, terrorist attacks in Western Europe, etc.). In their interpretation of these events, the alternative news sources declare their efforts to balance out the allegedly unilateral pro-Western orientation of the mainstream media, depicting the policy of the West as the actual source of these crises and catastrophes.

In this paper, I aim to outline my efforts to seek the historical roots of this type of representations, assuming that many conspiratorial interpretations of the recent events are based on handed-down ethnic group images and stereotypes of Us and Them. Actual research on conspiracy beliefs indicates that "people are more likely to entertain as possibly true beliefs with which they are familiar and which they know are fairly widespread" (Crocker et al. 1999). I will demonstrate the issues mentioned above on the basis of sources reflecting both contemporary and historical discourses (actual news and discussions on the Internet, the nineteenth and twentieth century literature and press). This paper relates to the Slovak political and cultural context, although it is clear that this context can be very similar to the realities of other countries as well.

\section{THE IMAGE OF THE WEST IN THE CURRENT CONSPIRATORIAL DISCOURSE IN SLOVAKIA}

From the psychological perspective, conspiracy theories can be viewed also as specific verbal expressions of enmification (a term used by Rieber and Kelley (1991)), psychological factors leading to the process of 'enemy making'. 
Enmification develops through the psychological processes of stereotyping, selective perception, mirror-imaging of the enemy, dehumanization, biased attributions, attribution errors, and the psychological need to have an enemy (Fabick 2007: 74).

The image of the West as the source of conspiracy activities against Us (the nation) is sometimes interpreted as an effort to shift responsibility for (real or fabulated) negative phenomena and threats from the inside out onto the external enemy (Šebej \& Vašečka \& Nič 1998). On the other hand, the success of conspiracies depends on the actions of the 'internal enemy', an agent that disrupts our ideal world and manages to cross the border between Them and Us, unnoticed. Henri Zukier has described it as follows:

Conspirators, as the product and agents of a rupture in group solidarity, are typically internal rather than external enemies, who undermine society from within. International conspiracies are contrived within the bound of the land. The conspiracies reach far out, but unfold in the immediate proximity. The plots are hatched by strangers to society, but not by foreigners... (Zukier 1987: 99)

From the perspective of the political struggle, an important role in the construction of the story is played not so much by the conspiracy centre outside (because this is an unquestioned fact), but by its 'extended hands' - internal traitors, accomplices, and collaborators. It is them who are supposed to be the target: although physically easily reachable, the fight against them requires special public support. ${ }^{3}$ In anti-Western rhetoric, this refers to the 'henchmen of the West' or the 'cronies of Brussels', whose networks are spread mainly by pro-liberal non-profit organisations, 'homolobby', or - in the slang of internet debates - manipulated and naïve 'sunpeople' (slniečkári in Slovak).

Over the past two years, the events related to the political crisis in Syria and Ukraine, as well as the migration crisis, have been particularly reflected in Slovakia, in the narratives that had the nature of alternative news coverage, hoaxes, and conspiracy theories with a single objective - to find explanations and designate the culprits. Two opposite parties arose in the public discourse, as observed in politicians' statements, news reports, blogs, and internet debates. One of them, which we could designate as supporters of the West, defends Ukraine's efforts to join the European structures, rejects the occupation of Crimea, and usually also expresses support for help to war refugees. These attitudes are shared by the mass media considered as liberal mainstream (SME, DenníkN, ${ }^{4}$ etc.) and also by President Andrej Kiska. On the other side, there are currents of opinions refusing Slovakian membership of the European Union and NATO, the granting of asylum to refugees in Europe, and supporting Vladimir Putin's 
policy. This discourse is shared mainly by the alternative news sources (internet news websites such as Denník politika, Zem a Vek, Hlavné správy, ${ }^{5}$ etc.).

The most successful alternative media in Slovakia include the Zem a Vek magazine with Eliot Rostas as its founder and chief editor. ${ }^{6}$

In the article "Vládne nám tieňový establišment?" (Are we ruled by shadow establishment?), the image of the West is depicted as follows:

European values (often referred to by NGOs) mean one thing on the paper, and another thing in practice... What is the content of activities of uncontrollable non-governmental organisations paid by the West-so-called non-profit organisations, foundations, civic associations, institutes, etc.? If you think that it is human rights, women's rights or the rights of minorities, you are completely mistaken. These noble activities hide, in fact, cold careerism, the assumption of political and economic power accompanied by the implementation of neoliberal reforms and, especially, destruction of society in the Ukrainian way ('Maidanisation'). The parallel state that they have successfully created has its tentacles in the entire cultural sphere, and its activities include, for example, the dissemination of pro-Atlantic, neoliberal, anti-Russian, militant (officially security) propaganda against the alternative media and alternative concepts (officially called hybrid war); propaganda against the nation (artificial creation of the so-called European identity), against spirituality (mocking of believers, radical secularisation through consumption), against tradition (discontinuity), against the socialist ideas of co-operation (words like nationalisation are automatically associated with 'totalitarianism', 'lack of freedom'; this, naturally, relates to the official ideology of the unrestricted free market and neoliberalism); and against the questioning of the establishment and, in particular, for legitimisation of the establishment through all ideological structures of the system (as Noam Chomsky called them)... (Perný 2016)

In their politics-oriented agenda, alternative websites, which declare themselves Christian and present ultra-conservative and conspiracy-oriented attitudes, ${ }^{7}$ perceive the contrast between the East and the West in the apocalyptical rhetoric of the approaching open conflict. They share posts which see in Putin's Russia a source of protection of traditional values against the 'decadent West' - one of the popularly shared post is translation of the article by Patrick J. Buchanan, titled "Whose Side is God on Now?", which states, among other things: "With Marxism-Leninism a dead faith, Putin is saying the new ideological struggle is between a debauched West led by the United States and a traditionalist world Russia would be proud to lead." 
What is common to both sides is the blaming of the ideological opponents promoting foreign propaganda and, hence, conspiracy against their own nation. There are also several political studies that directly blame the Russian Federation for propaganda and the dissemination of conspiracy theories, bringing information about direct personal links between alternative media editors and Russian politicians, for example:

Russia is operating remarkable (wartime) propaganda machinery on the extreme right-wing and / or conspiratory online platforms and social media pages created in 2013 and 2014, which combine pro-Russian attitudes with conspiracy theories and anti-Western sentiments. One of the Russiafriendly media personalities is known to have close ties with the godfather of the Eurasianist ideology, Alexander Dugin. (Krekó et al. 2015: 12)

On the other hand, alternative news sources present with the same intensity theories about conspiracies by non-governmental organisations, NATO, the European Union, and the USA in provoking protests in the Ukrainian Maidan, the civil war in Syria, and the refugee crisis.

The anti-system and anti-Western rhetoric managed to combine seemingly antagonistic ideological groups - as, for example, right-wing nationalist radicalism and ultra-conservative Christian movements, ${ }^{9}$ as manifested directly during the elections to the Slovak Parliament on March 5, 2016. This cooperation was successful and thanks to the unexpectedly high number of votes, the right-wing Ludová strana - Naše Slovensko (People's Party - Our Slovakia), led by Marián Kotleba, entered the parliament for the first time.

During and after the campaign, this party was officially supported by Magnificat Slovakia (see endnote 7). This ultra-conservative party, originally aimed to promote the Marian movement (particularly apparitions of the Virgin Mary) is now focusing also on the fight against what they perceive as manifestations of the New Age movement, including freemasonry and the establishment of the New World Order. In his call to support Marián Kotleba, the founder of Magnificat, Anton Selecký, stated:

Quarter of a century after the Velvet Revolution we can notice that there has been no expected spiritual revival of the nation and economic development. On the contrary, Slovakia has lost its self-sufficiency in energy and food and its defence capability, and has become a semi-colonial outlet of foreign products. This situation is the result of external forces and treasonable activities of some domestic politicians. The only positive change was the restoration of Slovakia's independence. After economic and social destruction, our Western allies have forced us to accept moral perversion in the form of gender ideology and, lately, under the disguise 
of insidious solidarity, admit thousands of non-integrable Muslim immigrants. It is obvious today that the aim of controlled immigration is to destroy European nations and states and, in particular, the Christian roots of Europe. The invasion of immigrants continues hand in hand with the aggressive policies of the US and the West against Russia and distracts attention from them. The aim is to provoke a new global conflict, which would be beneficial mainly for the US... Let us not lose this unique opportunity. Much is at stake; it is about the survival of the Slovak Republic and of the Slovak nation, and about the future of our children. Let us decide according to our conscience, and not according to the propaganda of aggressive, hateful media or manipulated and bought election polls.

The most fervent issue in recent times that has turned the social debate in Slovakia towards a conspiracist discourse has been the issue of refugees seeking to get to Germany through the Balkans and Central Europe. The fact that the German Chancellor Angela Merkel demonstrated her willingness to admit refugees triggered a strong response among conspiracy theorists, for whom this represented a clear proof that Merkel was in the pay of conspirators who are now preparing, together with Brussels, the end of the European civilisation. ${ }^{10}$

The alternative news sources have tried to create an impression that the migrant influx is not caused by the war events in the Middle East, but that it is in fact merely a certain form of targeted efforts of the conspirators controlling global policy (USA) on Islamise Europe, undermine its traditional values and cultures, and bring about ethnic and economic destruction. In this connection, I would like to mention extremists' anti-migrant march that took place in Bratislava on June 25, 2016. Hundreds of extremists marched through Bratislava on Saturday afternoon in protest against the acceptation of what they called the "liquidation of Europe and Brussels' dictate". (A counter-protest called Anti-Fascist Mobilisation took place simultaneously with the protest of the extremists. Hundreds of people gathered there to march through the city, too.) During the march, extremists held banners reading "Together for Slovakia" and "Slovaks in Heart", and shouted slogans like "Slovakia to Slovaks", "We Don't Want Multi-Culti", and "We Are at Home Here". Marián Magát, who was running for Marián Kotleba's party in the March general election, moderated the event. In addition to Slovaks, Czechs, and Germans, Croatians and Serbs took part in the anti-migrant march. In their speeches, participants in the protest touched the issue of Brexit and expressed their interest in arranging a referendum on Slovakia's exit from the European Union. The event ended in an improvised trial of politicians (Slovak president Andrej Kiska and Prime Minister Róbert Fico) they wanted to hang. 
On the Internet, refugees have been depicted in numerous hoaxes as a threat which brings, in addition to thousands of culturally incompatible, socially dependent, uneducated, and naturally violent people, also dangerous exotic diseases (one of the internet hoaxes was about an outbreak of the West Nile fever epidemic in Vienna, illustrated by photographs of an immigrant boy with bleeding eyes, intentionally transferred from articles about a completely different type of disease - dengue fever). ${ }^{11}$ Rumours of this kind, naturally, excite public interest and support the traditional image of the 'Stranger' perceived as a kind of cultural and/or biological contamination. As summarised by Gary A. Fine and Bill Ellis (2010: 74) on examples from American narrative culture, "waves of migrants were targets of stereotypes that portrayed newcomers as the purveyors of disease, immorality, and even disloyalty". Their research points out the common tendency of anti-immigrant rhetoric to perceive immigrants as tools of the enemy's conspiracy. ${ }^{12}$ Rumours and urban legends often concentrate on depicting strangers as barbaric, immoral, nasty, and disgusting (bloodthirsty slashers, child kidnappers, animal abusers, etc.). In 2016, among many antiimmigrant hoaxes inspired by contemporary legends were particularly poignant allegations of assaults of children in Slovakia or the Czech Republic. ${ }^{13}$ As a reaction, a parody on a variant of a white (or, in this case, black) van was created and spread in the social networks in November 2015 (Fig. 1) ${ }^{14}$.

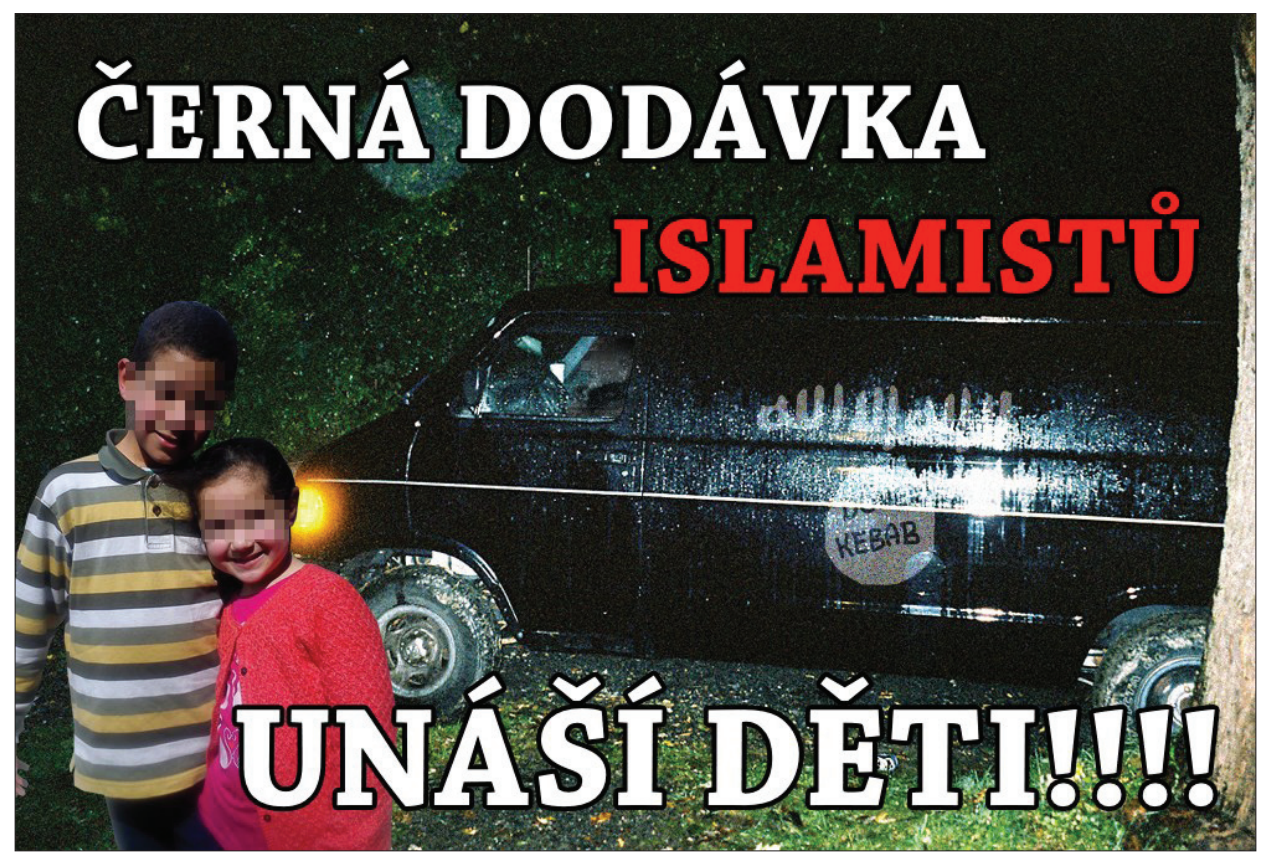

Figure 1. "Islamists' black van is kidnapping children!!!" A hoax spread via Facebook in November 2015. 


\section{THE IMAGE OF THE WEST IN SLOVAKIA IN THE HISTORICAL CONTEXT}

Interesting results arose from public opinion polls conducted among the citizens of the Visegrad Four (V4) countries (Slovakia, the Czech Republic, Poland, and Hungary), which were concerned, among other things, with trust towards the USA and the Russian Federation. According to the survey carried out from May to July 2015 (Gyárfášová \& Mesežnikov 2016), Slovak citizens showed the biggest trust towards the Russian Federation and the smallest towards the USA, as compared to the citizens of the neighbouring countries. The authors of the research report interpreted these data as follows:

The low level of trust towards the United States, which sets Slovakia apart from other V4 countries, can be interpreted as a result of a wide range of historical, ideological, socio-cultural and socio-economic factors, which shaped the public opinion in favour of Russia. These factors include attitudes of some representatives of nineteenth-century national intellectual elite (Ludovít Štúr, Svetozár Hurban Vajanský), leftist intellectuals in the inter-war period, and Slovak communists in the period of 1948-1989. (Gyárfášová \& Mesežnikov 2016: 22)

Similar statements describing the anti-Western attitudes in Slovakia towards the nineteenth-century political sentiments can be found on the Slovak Internet websites in the statements of the Slovak nationalistic ultra-right-wing movements, as well as in the political comments in Slovak dailies. On April 22, 2016, a Slovak daily DenníkN published a blog written by Michal Bábik, who raised the following question:

The blood conflict in Ukraine divides not only Ukraine, but also many of us - in the media, in blogs or social networks. Ukraine literally polarises us: Are we the West or the East, NATO or Russia, whisky or vodka? Where do we belong? It is not for the first time at all that we are raising this question - two hundred years ago, it was raised by our 'founding fathers'national revivalists. (Bábik 2016)

Let us look, for example, at the images of the West in the first half of the nineteenth century, when the Slovak nationalist worldview was being established. The most prominent personality of the Slovak national movement was Ludovít Štúr (1815-1856), professor and deputy of the Hungarian Parliament, who died 150 years ago. In his work Slavdom and the World of the Future, which is (somewhat exaggeratedly) considered his political testament, he depicted his political visions in the manner that became determining for the next generations 
of Slovak nationalists, whose basic ideological scheme was based on emphasising the opposition between the East and the West. The West was described by Štúr as follows:

As noted above, the West is willing to be free on all sides and exercise the principle of freedom which was regained or which arose from historic developments; it wants to be independent from the absolute power of the church, the state, etc., but what do these efforts look like?... The emancipated West... is running away from churches just like prisoners released from prison, rushes into all kinds of pleasures, and everyone fully enjoys the pleasures as if they wanted to compensate for their self-denial, previously enforced by religion...

Fun and pleasure are common words of the day; any means is good to achieve them; and then we see those horrific crime processes in France, trying people for the most barbaric devilries, the most condemnable crimes, such as poisoning, malicious murders because of marital issues, etc. There are devilries and immorality also elsewhere, but these are rather exceptions from the rule, seeking to hide in the darkness; however, in the West, such cases occur in broad daylight, and are even claimed to be right, seeking to be recognised by law, and many even show their pride in them....

Slavery is present also in the United States, and we know with what cruelty English and French colonialists treat their slaves, yet this paganism is equally condemnable, and humanity is raising its voice against it more urgently every time...

There is no peace and stability, everything is being moved and rushed forward, and all see their final, much-sought-for happiness-in perdition! One revolution will follow another, and each time the Western nations will be in a worse situation than before...

Where to turn our sight, from where to draw hope, if the heart that flamed up with love for humans vainly seeks help in the West? Over there, in the far East, because this is where the Slavic nation, the nation of the future lives!... Russians are the only ones among Slavs who preserved their independence and thus saved the reputation of the Slavic name... The only Slavs that feel hostility towards Russians and would act against them if they had the opportunity are the Polish. The Czechs have not shown very brotherly feelings towards Russia recently, which is regretful, indeed, and their books have even been filled with hatred. (Štúr 1993 [1853]: 67, $71,76,114)$

Just like in other countries, it was popular also among the members of intellectual elites in Bohemia and Hungary in the nineteenth century to pursue 
an authentic way of life, not affected by any modern Western influences. The seeking of authenticity in the framework of the romantic image of morally and culturally 'unspoiled' Slovakia as opposed to Bohemia marked by modernisation was part of the rhetoric of the Czech-Slovak cultural cooperation at the turn of the twentieth century. Hereby I would like to offer as an example a reflection by Alois Kolísek, a Czech Catholic priest and supporter of independent Czechoslovakia, written in $1918:{ }^{15}$

The fact that the nature of our nation is in its purity, free of foreign influences (i.e. influence of the Western culture - Z. G.) and basically the same as, for example, in Hungary, is proven by the moral attributes of our people... Not only our language and phraseology are eager to find pure sources of fresh revival. Our spiritual culture also requires it. Not having Slovakia today or tomorrow will be the same as petrifying the Czech spiritual crisis... (cited in Galiová 2003: 114)

Another example is a letter by a Czech intellectual, Marie Smolková, dedicated to Slovak folk art:

There are concerns that the flow of the era penetrating from the West, which has already destroyed so many original things here in Bohemia, dragged us into oblivion and also affected Moravia, extends its harmful effects to Slovakia in Hungary. (Smolková 1896: 50)

At the political level, the period of the Slovak State (1939-1945) and its authoritarian leadership regime following the example of Mussolini's Italy is characterised by the victory of Slovak nationalism and conservatism over the liberal-oriented inter-war Czechoslovak Republic (1918-1939). The official press supervised by the Propaganda Office brought topics of Freemasonry and Jewish and Jewish-Bolshevik conspiracies in the public discourse about the enemy of the nation and Christianity along the lines of German Nazism. The image of the West as morally rotten and leading to a moral disintegration of society, a warmonger allied with Jewish conspirators, is also typical of the rhetoric of Slovak nationalism during World War II. The images of an American and an Englishman, dominated by the features of a rich, greedy businessman, considerably overlap. There is a similar feel of resentment towards the financially successful 'other', just like with the image of a Jew. The moral rectitude of Americans is also discredited by the arms trade (Fig. 2); in the case of a Brit (or an Englishman) it is the attribute of a coloniser who has no moral right to pretend to be a human rights defender (Fig. 3). 


\section{Sviečku páli Bohu i čertovi.}

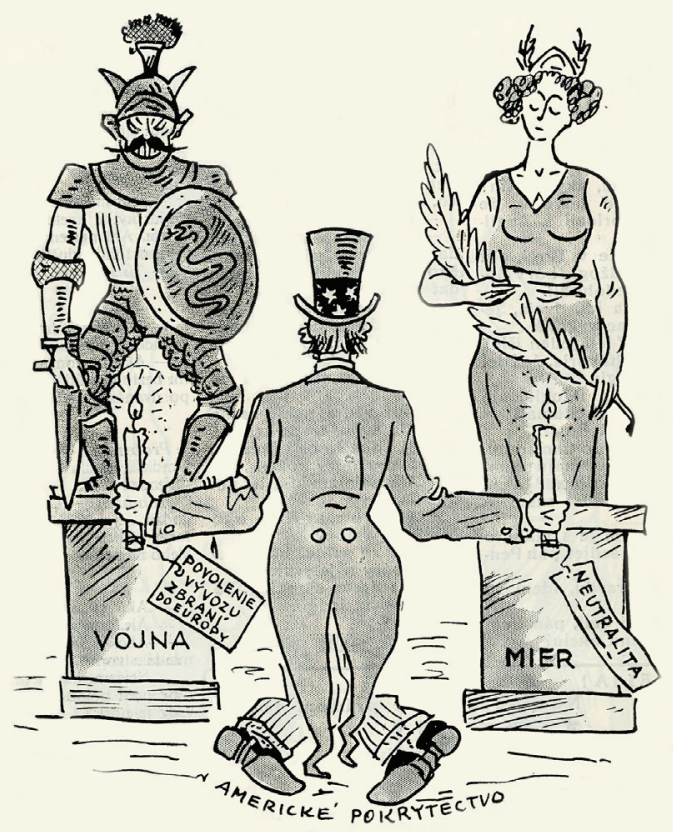

Figure 2. He is burning the candle both to God and the devil. (Kocúr, No. 9, 1939, p. 72)
Figure 3. A world ruler: "The existence and power of England depends on the balance." (Kocúr, No. 14, 1941, p. 168)

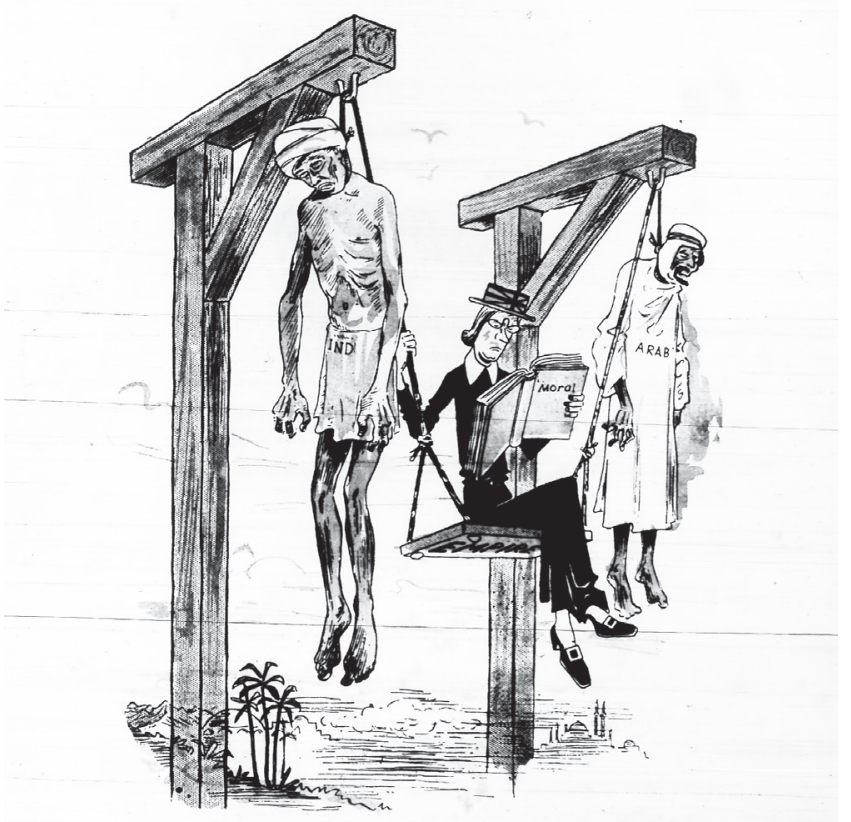

Svetovládca: „Existencia a moc Anglicka závisí od rovnováhy.“ 
In the non-Communist press published in the period immediately after the end of World War II and before the communist coup (from May 1945 to February 1948) we can rather observe neutral or positive images of the West, stressing its technological development. Especially in the case of the USA, we can read travel information bringing exciting stories about their achievements. (This fascination is probably reflected in a variant of the motif of the 'eaten-up granny'. The stories are about a family living in Czechoslovakia right after the end of World War II, receiving a strange mail - a tin filled with dust and bones, sent, according to the postwoman, by the humanitarian organisation of the United Nations Relief and Rehabilitation Administration (UNRRA) ${ }^{16}$. Thinking that it is a kind of a modern western way of instant food treatment, the family adds the tin content to the cabbage soup and eats it - though with disgust. A couple of days later the family receives a shocking message - a delayed telegram about the death of their American granny who wished to be buried in her home country. Hence, the mail was not about 'UNRRA', but 'urna' (Slovak expression for an urn, a vase for holding the ashes of the cremated dead) (Panczová 2013: 144-145).

The victory of the Communist Party in Czechoslovakia in February 1948 was accompanied by the establishment of a totalitarian regime and gradual consolidation of the ideological image of the West. In the next years, this image became the object of accusations of efforts to start a new global world conflict.

The first opportunity of the kind was the conspiratorial interpretation of the Marshall Plan, disseminated in the Czechoslovak press after 1948. Examples of this include newspaper articles such as "Dollar Bringing the West Together. Marshall Plan Approved. Potsdam Agreement Degraded”, which states:

The events, as they fit together, make it clear to every thinking person that it is about turning aside Western European countries, supported by millions of dollars against the Soviet Union as the biggest stronghold of eastern democracies... It is no exaggeration to think that these are the signs of a new war, a new global fire. (Týždeň 1948: 1)

In the official discourse, it is the USA, i.e., America, which became the absolutisation of the West in the political and moral sense. The image of America serves as the essence and source of everything, representing the opposite between the West and the East. In the 1950s, the press started to publish a deluge of articles and caricatures in which the image of the West (including America) was associated with attributes of violence, debauchery (prostitution, frequent change of life partners), lack of progress (superstitions), warmongering warmongers compared to the Nazi (Fig. 4), and social injustice (racism - the image of the $\mathrm{Ku}-\mathrm{Kl}$ lux-Klan, differences in property, unemployment, hunger). The personified 


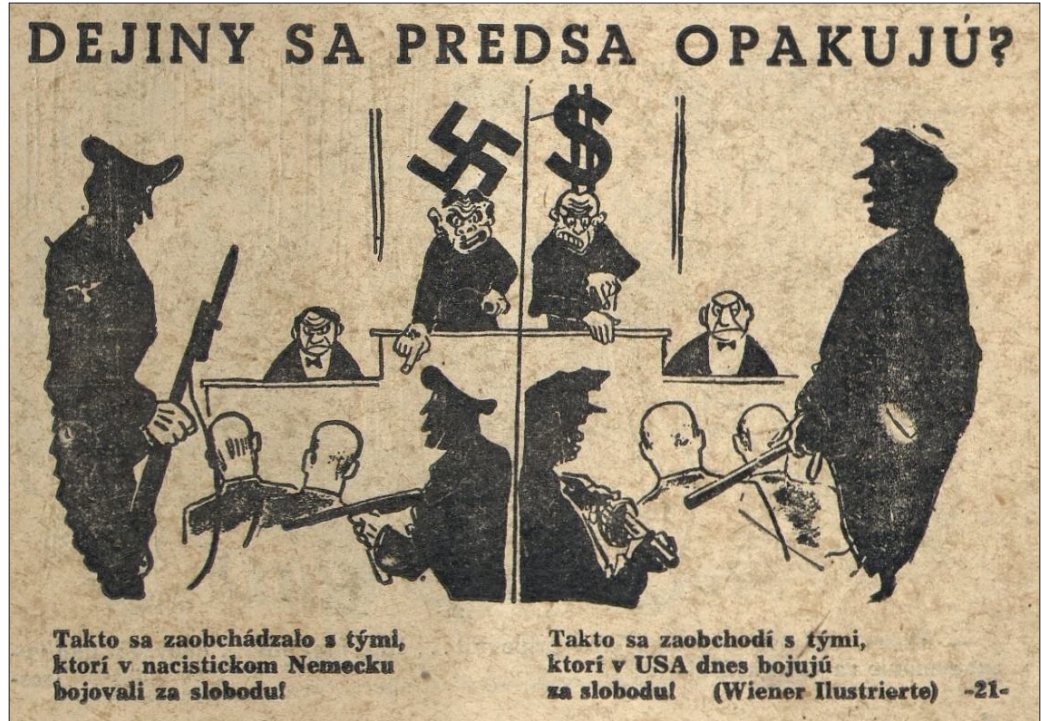

Figure 4. History still repeats itself. (Roháč, Vol. 3, No. 12, 1950, pp. 2-3)

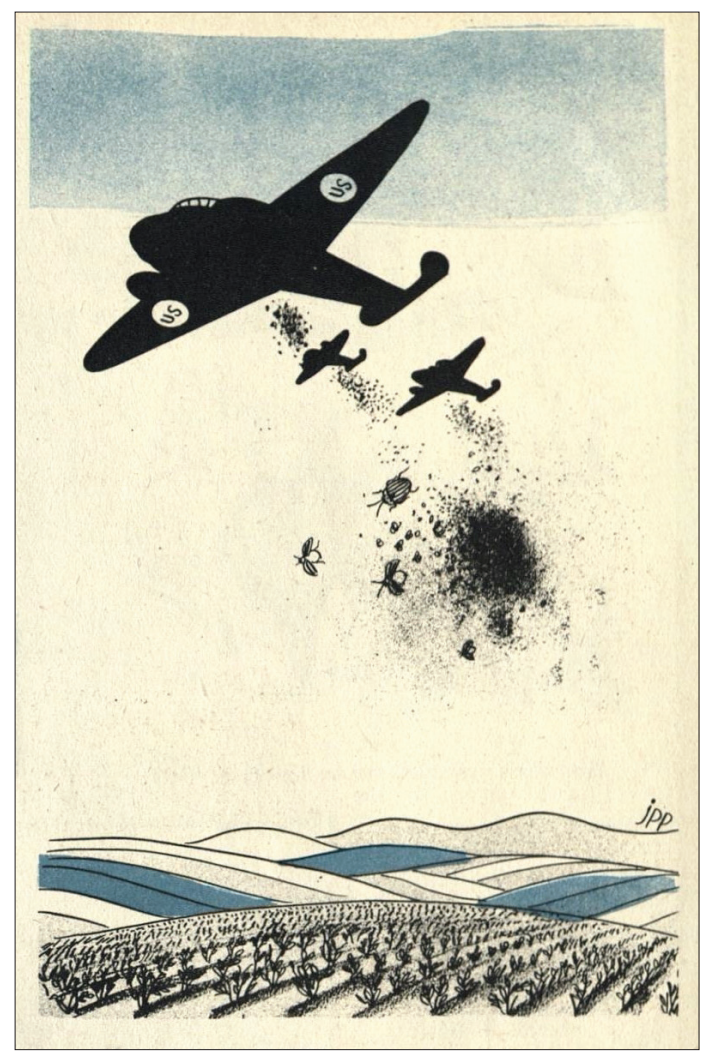

Figure 5. 'Western imperialists' intentionally dropping 'American bugs' (potato beetles) onto the fields of Central Europe, causing a plague. (Roháč, Vol. 3, No. 25, $1950, p .11)$ 
West was represented by comic figures of politicians - Churchill as an alcoholic, Eisenhower as a Nazi, and Truman or Acheson as warmongers.

This propaganda was nurtured by occasionally spreading conspiracy theories, such as reports about the use of a biological weapon - potato bugs (Fig. 5) - or support of conspiracy versions of the background of Kennedy's murder. The Czechoslovak press sought to use conspiracy theories concerning J. F. Kennedy's death in 1963 for its propaganda purposes. In its reaction to this event, the press jointly emphasised the "unhealthy violent atmosphere of the American society" with its deep-rooted "self-conceit and superiority", and hinted at the actual offenders from among ultra-right wing organisations and other political opponents of Kennedy's politics, stressing the role of the police and the FBI in concealing evidence:

Overall, there is no doubt that the same forces that have recently led to the actions against black people stand in the background of the assassination... If, however, they manage to present the offender as a madman or if there are even attempts to identify him with Communists, the situation can become very serious, as many observers pointed out... There are even rumours that the whole affair was an attempt of the extreme right to measure the forces, planning to use the heated atmosphere, etc. (Pravda 1963: 1, 3)

The period after 1989 was characterised by euphoria from the regained freedom and big expectations from improved standards of living; on the other hand since the key state institutions and their representatives were not prepared for the changes - we could witness 'wild' privatisation based on stealing the previously national assets, increasing trends of chauvinist nationalism, official emergence of unemployment, homelessness, and the birth of mafia organisations. At the same time, people could easily get into contact with different types of protest movements, radical nationalist and religious subcultures, which were based on conspiratorial ideological schemes and became, together with known stereotypes of national enemies, an inspiration for the conspiracy culture in Slovakia. Shortly after the political change, which ended the forty-year period of the communist totalitarian regime in November 1989, theories revealing the actual background of this event started to be disseminated (for more information see Panczová \& Janeček 2015: 161-162), linking the strings pulled from Washington to the Jewish-freemasonic profile of the main actors (as, for example, president Václav Havel). 


\section{CONCLUSION}

The analysis of the Slovak alternative news websites suggests that their resistance against the existing system is almost always linked to the negative image of the West. There are several reasons why this type of news is so successful in Slovakia at present. One of the undoubted factors is that they use the images and ethnic stereotypes that have been verified and refined through handing down from generation to generation, and used by the propaganda of different political regimes and, in addition, supported by the authority of important personalities in the Slovak national history. This article has shown that the attributes of the West, as spread by conspiracy theories in Slovakia, have been handed down for a minimum of 150 years. The stereotypical images of the USA and the West as societies full of violence, corruption, scandals, deep social inequalities, and moral and cultural decadence represent, even today, a valid principle, according to which the USA and the West act in the role of the enemies of the nation against the Messianic images of the East. The dynamics of the dissemination of conspiracy theories within the Slovak internet space today is characterised by the creation of two considerable rivalling platforms linked to different news categories (pro-Western mainstream vs. pro-Eastern alternative sources) and their mutual discursive interaction. The attitudes towards the West (or the East - which is, however, a less frequent topic) are among the main indicators of affiliation to the respective ideological platform in this rivalry.

Certainly, this paper presents this topic in a very simplified way, since the dissemination of conspiracy theories is influenced by many factors. Awareness about the historical specificities of the context in which conspiratorial attitudes towards the West have been spread in Slovakia forms the basis for the planned European-wide comparative research on this topic.

\section{ACKNOWLEDGEMENTS}

This article was supported by the grant project VEGA 2/0126/14, "Continuity and discontinuity in ethnological research regarding intangible cultural heritage".

\section{NOTES}

1 The historic forms of conspiracy theories and political rumours were studied, for example, by Ploux 2003 (according to Campion-Vincent 2005: 108); Zukier 1987; Poliakov 1987; Groh 1987a, 1987b; etc. 
2 The rivalry between mainstream and alternative in Slovakia has also acquired a form of producing lists of websites, articles or persons that seek to uncover, condemn publicly, and show the links between seemingly independent information sources from the 'other side' (see, for example, www.konspiratori.sk, http://www.poznanie.estranky.sk/ clanky/kto-za-koho-kope-cast-2.html, and http://prop.wz.cz/kto_za_koho.htm, all last accessed on June 16, 2017).

3 In the context of the Nazi propaganda, these were the domestic Jews, members or supporters of opposition parties, as well as 'white Jews', i.e., those members of the 'white'/'Us' category, who were, for various reasons, convicted of sharing the Jewish identity (Panczová 2015: 249).

4 See https://www.sme.sk, https://dennikn.sk/, both last accessed on June 16, 2017.

5 See http://dennikpolitika.sk/, http://zemavek.sk/, http://www.hlavnespravy.sk/, all last accessed on June 16, 2017.

6 The average annual circulation of this monthly magazine in 2015 was 25,000 copies; according to the chief editor, they have around 7,000 subscribers. Source: public debate Havranovo talk show (May 27, 2015); guests: Tibor Eliot Rostas and Juraj Smatana (record of the debate is accessible at https://www.youtube.com/watch?v=ONr6uHADhM, last accessed on June 16, 2017).

7 For example, Slovakian LifeNews (www.lifenews.sk, last accessed on June 16, 2017), medium of the conservative Institute of Leo XIII, inspired by the encyclical of this pope, Humanum Genus, against freemasonry.

Politically active is the Magnificat Slovakia - a citizens' association, publishing house, and since 2012 also a political party, originally aimed to disseminate messages from the alleged apparitions of Virgin Mary. Its webpage mainly publishes translations of articles from foreign alternative sources in the sections "Freemasonry" and "World governance", jointly included in the New Age category. The titles of the articles are, for example: "The essence of the totalitarian European Union", "Slovaks fight for Slovakia against Americans!", "President Kiska (crony of the US and their lies - comment) arrived in Kiev to attend the Pride" (see http://www.magnificat.sk/, last accessed on June 16, 2017).

8 See http://buchanan.org/blog/whose-side-god-now-6337, last accessed on June 16, 2017.

9 The questions about ideological links between these worldviews would be subject for a deeper analysis as it is a complex phenomenon deserving further study.

${ }^{10}$ See http://www.magnificat.sk/aktualne-vyzva-pre-slovensko/, last accessed on June 16, 2017. A similar spirit can be observed in the article by a Russian reporter Darya Aslamova in Komsomolskaya Pravda (August 25, 2015, see http://best.kp.ru/msk/ europe_migrants/, last accessed on June 16,2017), the translation of which was shared by dozens of alternative websites in Slovakia and the Czech Republic.

${ }^{11}$ See Denník politika, September 15, 2015. Available at http://dennikpolitika.sk/voviedni-sa-siri-zapadonilska-horucka/, last accessed on June 16, 2017.

${ }^{12}$ For example, in US anti-immigration discourse Mexicans and Mexican Americans were sometimes depicted as 'bioweapons'. This term was used also in connection with 
the threat of the swine flu pandemic in 2009, which was interpreted as an artificial bioweapon manufactured by Islamic terrorist (Fine \& Ellis 2010: 75). There are many similar examples from other cultures, after all; we could mention the nineteenth and twentieth century anti-Semitic likening of Jews to cancer, insects or parasites (see, for example, Slovenský obrázkový antisemitský kalendár na rok 1886 (Slovak AntiSemitic Picture Almanac for 1886), pp. 18, 36, 44).

${ }^{13}$ For example, the story about a little boy allegedly assaulted by refugees in the asylum camp in Gabčíkovo (spread via Facebook in 2015; a dementi was published on http:// www.topky.sk/cl/10/1513359/Na-webe-sa-siri-obludne-klamstvo--Emotivny-pribehmatky--ktorej-utecenci-dobili-syna-v-Gabcikove, last accessed on June 16, 2017).

${ }^{14}$ See https://www.facebook.com/STOPxenofobii/posts/895415927172227, last accessed on July 11, 2017.

${ }^{15}$ In Slováci do státu československého (Slovaks to the State of Czechoslovakia).

16 The purpose and functions of the UNRRA were "to plan, coordinate, administer or arrange for the administration of measures for the relief of victims of war in any area under the control of any of the United Nations through the provision of food, fuel, clothing, shelter and other basic necessities, medical and other essential services" (see http://www.ibiblio.org/pha/policy/1943/431109a.html, last accessed on June 19, 2017).

\section{BIBLIOGRAPHY}

Humour magazine Kocúr (1919-1945)

Magazine Týždeň: prehl'ad svetových, hospodárskych a kultúrnych časovostí (1946-1951) Humour magazine Roháč (1948-1991)

Magazine Zem a Vek (2013-)

Daily Pravda (1944-1989)

\section{REFERENCES}

Bábik, Michal 2016. Ukrajinský konflikt z pohl'adu našich otcov zakladatel’ov. [Ukrainian Conflict from the Perspective of Our Founding Fathers.] DennikN, April 22. Available at https://dennikn.sk/blog/ukrajinsky-konflikt-z-pohladu-nasich-otcovzakladatelov/, last accessed on June 19, 2017.

Barkun, Michael 2013. A Culture of Conspiracy: Apocalyptic Visions in Contemporary America. Comparative Studies in Religion and Society 15. Berkeley \& Los Angeles \& London: University of California Press.

Campion-Vincent, Véronique 2005. From Evil Others to Evil Elites: A Dominant Pattern in Conspiracy Theories Today. In: Gary Alan Fine \& Véronique Campion-Vincent \& Chip Heath (eds.) Rumor Mills: The Social Impact of Rumor and Legend. New Brunswick, N.J. \& London: Aldine Transaction, pp. 103-122. 
Crocker, Jennifer \& Luhtanen, Riia \& Broadnax, Stephanie \& Blaine, Bruse Evan 1999. Belief in U.S. Government Conspiracies against Blacks among Black and White College Students: Powerlessness or System Blame? Personality and Social Psychology Bulletin, Vol. 25, No. 8, pp. 941-953. https://doi.org/10.1177/01461672992511003.

Fabick, Stephen D. 2007. Two Psychologically Based Conflict Resolution Programs: Enemy Images and US \& THEM. Journal for Social Action in Counseling and Psychology, Vol. 1, No. 2, pp. 72-81.

Fine, Gary A. \& Ellis, Bill 2010. The Global Grapevine: Why Rumors of Terrorism, Immigration, and Trade Matter. New York: Oxford University Press.

Galiová, Zuzana 2003. Alois Kolísek - kňaz, politik a propagátor slovenskej kultúry. [Alois Kolísek - A Priest, Politician, and Propagator of the Slovak Culture.] Ethnologia Slovaca et Slavica, Vols. 30-31 (1998-1999), pp. 113-128. Available at http://alis.uniba.sk/storage/uk/fif/acta/ID_354_146501.pdf, last accessed on July 12, 2017.

Groh, Dieter 1987a. The Temptation of Conspiracy Theory, or: Why Do Bad Things Happen to Good People? Part I: Preliminary Draft of a Theory of Conspiracy Theories. In: Carl F. Graumann \& Serge Moscovici (eds.) Changing Conceptions of Conspiracy. New York \& Berlin \& Heidelberg \& London \& Paris \& Tokyo: Springer Verlag, pp. 1-14.

Groh, Dieter 1987b. The Temptation of Conspiracy Theory, or: Why Do Bad Things Happen to Good People? Part II: Case Studies. In: Carl F. Graumann \& Serge Moscovici (eds.) Changing Conceptions of Conspiracy. New York \& Berlin \& Heidelberg \& London \& Paris \& Tokyo: Springer-Verlag, pp. 15-38. Available at https://archive.org/details/CarlF.GraumannSergeMoscovicieds. ChangingConceptionsOfConspiracySpringerVerlagNewYork1987, last accessed on June 16, 2017.

Gyárfášová, Ol'ga \& Mesežnikov, Grigorij 2016. 25 Years of the V4 as Seen by the Public. Bratislava: Institute for Public Affairs. Available at http://www.ivo.sk/buxus/ docs//publikacie/subory/25_Years_of_the_V4_as_Seen_by_the_Public.pdf, last accessed on June 19, 2017.

Knight, Peter 2002. Introduction: A Nation of Conspiracy Theorists. In: Peter Knight (ed.) Conspiracy Nation: The Politics of Paranoia in Postwar America. New York \& London: New York University Press, pp. 1-17.

Krekó, Péter \& Gyốri, Lóránt \& Milo, Daniel \& Marušiak, Juraj \& Széky, János \& Lencsés, Anita 2015. Marching Towards Eurasia: The Kremlin Connections of the Slovak Far-Right. Political Capital Kft. and Social Development Institute Kft. Available at https://www.academia.edu/19730490/Marching_towards_Eurasia._The_Kremlin_ connections_of_the_Slovak_far-right, last accessed on June 16, 2017.

Panczová, Zuzana 2013. Humor a strach v poetike súčasných povestí. [Humour and Fear in the Poetics of Contemporary Legends.] Slovenský národopis / Slovak Ethnology, Vol. 61, No. 2, pp. 142-154. Available at http://www.uet.sav.sk/files/ etno2-2013-text-web.pdf, last accessed on June 19, 2017.

Panczová, Zuzana 2015. Images of the Traitor and Enemy in Humour and Political Cartoons in War-Time Slovakia: Analysis of the Magazine Kocúr. In: Dagnoslaw Demski \& Liisi Laineste \& Kamila Baraniecka-Olszewska (eds.) War Matters: Constructing Images of the Other (1930s to 1950s). Budapest: Instytut Archaeologii i Etnologii PAN \& Estonian Literary Museum, pp. 244-273. 
Panczová, Zuzana \& Janeček, Petr 2015. Théories du complote et rumeurs en Slovaque et en Tchéque. Diogène: Les théories du complot aujourd'hui, Vols. 249-250, pp. 150-167. Paris: UNESCO-IULM-Presses Universitaires de France.

Perný, Lukáš 2016. Vládne nám tieňový establišment? [Are We Controlled by Shadow Establishment?] Zem a vek, March 9. Available at http://zemavek.sk/articles/view/ vladne-nam-tienovy-establisment, last accessed on June 16, 2017.

Ploux, François 2003. De bouche à oreille: Naissance et propagation des rumeurs dans la France du XIXe siècle. Paris: Aubier.

Poliakov, Léon 1987. The Topic of the Jewish Conspiracy in Russia (1905-1920), and the International Consequences. In: Carl F. Graumann \& Serge Moscovici (eds.) Changing Conceptions of Conspiracy. New York \& Berlin \& Heidelberg \& London \& Paris \& Tokyo: Springer-Verlag, pp. 105-113. Available at https://archive.org/details/CarlF.GraumannSergeMoscovicieds. ChangingConceptionsOfConspiracySpringerVerlagNewYork1987, last accessed on June 19, 2017.

Pravda 1963 = Svet oceňuje politiku prezidenta Kennedyho. [World Appreciates the Politics of President Kennedy.] Pravda, November 24, pp. 1, 3.

Rieber, Robert W. \& Kelly, Robert J. 1991. Substance and Shadow: Images of the Enemy. In: Robert W. Rieber (ed.) The Psychology of War and Peace: The Image of the Enemy. New York: Plenum Press, pp. 3-38.

Slovenský obrázkový antisemitský kalendár na rok 1886. [Slovak Anti-Semitic Picture Almanac for 1886.] Budapest: Tiskom Imra Bartalitsa.

Smolková, Marie A. 1896. O ženskom domácom priemysle na Uhor. Slovensku. [On Women's Domestic Industry in the Upper Hungary.] Dom a škola, February 1, Vol. 12, No. 2, pp. 48-51.

Šebej, František \& Vašečka, Michal \& Nič, Marián 1998. Pohl'ady predstavitel’ov slovenských politických a spoločenských elít na bezpečnost’ a vstup SR do NATO. (Kauzálne atribúcie v hodnotení nezaradenia Slovenska do prvej skupiny kandidátov na členstvo v NATO.) [The Opinions of Representatives of Slovak Political and Social Elites on Security and Entry into NATO. (Causal Attributions in the Evaluation of Slovakia's Non-Inclusion in the First Group of Candidates for NATO Membership).] In: Martin Bútora \& František Šebej (eds.) Slovensko v šedej zóne? Rozširovanie NATO, zlyhania a perspektívy Slovenska. Bratislava: Inštitút pre verejné otázky, pp. 219-226.

Štúr, Ludovít 1993 [1853]. Slovanstvo a svet budúcnosti. [Slavs and the World of the Future.] Bratislava: Slovak Institute for International Studies.

Týždeň 1948 = Dolár stmeluje Západ. Marshallov plán odhlasovaný. Postupimská dohoda znevážená. [Dollar Bringing the West Together. Marshall Plan Approved. Potsdam Agreement Degraded.] Týždeň, March 20, p. 1.

Zukier, Henri 1987. The Conspiratorial Imperative: Medieval Jewry in Western Europe. In: Carl F. Graumann and Serge Moscovici (eds.) Changing Conceptions of Conspiracy. New York \& Berlin \& Heidelberg \& London \& Paris \& Tokyo: Springer-Verlag, pp. 87103. Available at https://archive.org/details/CarlF.GraumannSergeMoscovicieds. ChangingConceptionsOfConspiracySpringerVerlagNewYork1987, last accessed on June 16, 2017. 